\title{
"We only eat what we like" or do we still?
}

\author{
Georges M Halpern
}

\begin{abstract}
We humans only eat what we like, and we died when we could not find or were not given such food. The industry knows that well in affluent societies, and that is why (in part) we do have an epidemic of obesity. Ignoring the basic foundations of physiology (and survival) in the name of "science" perverted into "faith" is the perfect recipe for (criminal) failure! Eating/drinking is one of our basic needs; the others being sex, shelter, family/social support and skills. This did work pretty well in the pre- and early industrial age, but with industrialization of the food supply (agriculture, etc.), based on only limitless profit, we witnessed a tectonic perversion in politics, policies, physiopathology, epigenetics, and ultimately public health. The current quasi-unanimous attitude is to blame the victim (for example, the obese) and/or the messenger (for example, maybe this author).
\end{abstract}

Keywords: Food, Pleasure, Commensality, Industry, Perversion

When one thinks about food and oral intakes, and intends to share passion sprinkled with knowledge, ego and memories jump to the page. I discovered the pleasure of food when I started missing it during World War II in refugee camps in Switzerland. We were fed the same unappetizing gruel twice daily, and that lasted almost 18 months. Around me, older refugees ( $>65$ years old), formerly rich and hedonistic, discussed recipes from Auguste Escoffier, Ali-Bab, or Curnonsky; these ladies refused to swallow the brew they were served. They said: "We are not pigs. We are civilized, educated human beings with a palate, a taste, a culture". And they died, of self-inflicted starvation. They would only have accepted to eat what they liked. For these months and many, too many years after I thought of food every minute, every second; I dreamt of meals; I woke up craving for food, for fat cheeses, for aromatic sausages, for fresh-out-of-the-oven breads. I was obsessed. It never stopped. We know that we shall always like, love the food we liked, loved before the age of six. The foods, the dishes, the cuisines we pretend to like or even love later in life are very few. They are always judged against the enamored dishes we shared in our first childhood. I did not get these, or they were erased. I discovered the tastes of foods in 1947 in Denmark. Coming from France with its rationed 0\%-fat Camemberts, Marshall-plan maize bread I had landed in the Land of Fabulous Foods: smoked eels. Danish blue cheeses, endless charcuteries, real milk, soooo many

Correspondence: drgeorges@drgeorges.net

The Hong Kong Polytechnic University, Hung Hom, Hong Kong SAR breads, the freshest fish and seafood, legs of lamb, and the pastries that were served to the King... YES there was FOOD, endless, diverse, bringing happiness and joy -and health. It started my quest; it never ended; it never will.

What do we like in food? The list is long and openended. We obviously follow our senses: sight, smell, taste, texture, diverse sounds. We get messages from our genes, groomed for millennia. We do cherish memories and they rush back fast, very fast. We position food in its current environment, at times pleasantissime, at other times intolerable, but always in context. We eat stuff because we were told, or attracted/lured, brainwashed, coerced, by imitation or begging for inclusion, or even by challenge or curiosity. We also eat because it's time and we are hungry, because we need food if we drink, because of salt, or chili peppers, or gluttony, or..... Sometimes we are satisfied, or full, or happy, or frustrated. There's little rationality, no real rules, no foolproof recipe. It is you, now, then, there, in a given environment; and it will never be the same twice. Food is needed to live and survive. Some of our genes have been honed to perform in a hostile environment, the one that was the lot of the $>90 \%$ until the twentieth century. Sugar was introduced in the 1500s; fat was synonymous of feast until the 1900s; food was seasonal, and preserving it was difficult, random, expensive. In Warsaw, Poland (where I was born), ice from the Wisła (Vistula) was sliced in March, kept in caves and distributed over the summer and fall until the 1960s. Now, with concentration of production and mass distribution, any failure in the chain 
results in decimating food poisoning. The world has changed: Taylorism and industrial production, assisted by expert sociologists, marketers, psychologists, physiologists, nutritionists and other food scientists have managed to globalize food before any other human activity. When we know that the advertizing budget of CocaCola ${ }^{\circledR}$ is bigger than the GNP (gross national product (GNP)) of $>100$ countries of the United Nations, I feel humbled in composing this Op-Ed. What does the industry sell, why and how? It sells sweet and fat; it sells it at the lowest cost (= mass produced $)$ and maximal profit; it sells it everywhere with minimal differences; it sells it by bribing policy makers, and buying the whole chain of distribution; it sells it with some of the smartest scientists that consult or work there for transient illusion of glory and fortune; it sells it like the tobacco industry sells by targeting children and women [1]. And it works: in 2011, Nestlé was listed No. 1 in the Fortune Global 500 as the world's most profitable corporation; with a market capitalization of $\$ 200$ billion, Nestlé ranked No. 13 in the FT Global 2011 [2]. It has recently added Jenny Craig to its empire, the Jenny Craig that sells meals plus 2 snacks including an Anytime Bar that packs 110 empty calories in the daily ration of the US customer. The bucket of Kentucky Fried Chicken will deliver 3,000 kilocalories, mostly fats and carbohydrates, and I know many who eat that by themselves! I wrote that "the only natural thing in a Diet Coke ${ }^{\circledR}$ is the water" -if you accept that tap water (for example, Bonaqua $^{\circledR}$ ) is strictly natural; the revenue of the Coca Cola Company was US $\$ 46.5$ billion. Responsiveness to sugars and sweetness has very ancient evolutionary beginnings. Newborn human infants also demonstrate preferences for high sugar concentrations and prefer solutions that are sweeter than lactose, found in breast milk [3]; it also controls pain in preemies and newborns $[4,5]$. Sweetness appears to have the highest taste recognition threshold, being detectable at $\sim 1$ part in 200 of sucrose in solution. Sweetness intensity indicates energy density. The 'sweet tooth' thus has an ancient evolutionary heritage, and while food processing has changed consumption patterns, human physiology remains largely unchanged [3]. Then, recently two discoveries changed our food supply: a by-product of corn/maize, the high-fructose corn syrup (HFCS), and the artificial sweeteners. The HFCS is composed of a mixture of 42 to $55 \%$ fructose, 41 to $45 \%$ glucose and 0 to $5 \%$ glucose polymers depending on the specific blend. In the 1980s it mostly replaced sucrose as the main sweetener of soft drinks. Rates of obesity subsequently rose, paralleling an increase in the consumption of soft drinks in general. In addition, laboratory research suggests a link between consuming large amounts of fructose and various health problems e.g. high blood pressure, elevated blood triglycerides, size and type of low-density lipoproteins, and uric acid levels [6,7]. Worse, HFCS is addictive [8]. The most elaborate theory of sweetness to date is the multipoint attachment theory proposed by Jean-Marie Tinti and Claude Nofre in 1991. This theory involves a total of eight interaction sites between a sweetener and the sweetness receptor, although not all sweeteners interact with all eight sites [9]. This model has successfully helped to develop highly potent sweeteners, including the guanidine family with lugduname, about 225,000 times sweeter than sucrose [3]. But plasma beta-endorphin concentrations were more elevated after an aspartame drink than after the sucrose drink or fasting, and insulin increased after drinking as much with aspartame as with sucrose, meaning that possible addiction and obesity were right there with the sweetener [10]. The problem is that the palatability and enjoyment of foods are often tied to their energy density, and therefore fat content. Energy-dense foods that are rich in fat are more palatable than are many low-energydensity vegetables and fruit. High-fat foods, many containing sugar or salt, have an undeniable sensory appeal and are difficult to resist. There are many explanations for why humans like fat. Several physiological mechanisms have been proposed, many of which are based on the strong links found between fat content, palatability, satiety, and energy density. The orosensory properties of fat or fat "taste" are perceived through specific receptors and a combination of taste, texture, and olfaction. My friend Marian Apfelbaum, MD, a great nutritionist, starts his lectures on fat (and diet) by whispering into the microphone: "Fat tastes gooood; fat is gooood".

Indeed fat tastes and makes food taste very good. Fat is also a concentrated source of energy with rewarding post-ingestive effects. The learning of food preferences may be based on associating sensory attributes with the physiologic consequences of ingestion, such as satiety and well-being [11]. That is why the combination of sweetness and fat in fast or junk food is difficult to resist, and is eventually "as addictive as heroin" [12].

Getting a shot of opioids and dopamine to the brain while on the go, snacking on a dark penis-shaped bar full of industrial fats, and guzzling a supersized HFCS-laden drink is the city dweller's fate in many, and more countries. Then they get glued to the television that brainwashes with seductive ads promoting these products and that lifestyle. These "foods" and beverages are very smartly designed and created to appeal to our nucleus accumbens, and hedonic hunger [13].

Meals were and are shared; they are communion, conviviality, commensality (Claude Fischler's great neologism). We eat, not nutrients and calories, but foods, dishes, meals and we do so in specific places, at specific times and with specific people with whom we have interactions and relationships. Eating is not just individual behavior; it also consists of social practices and rituals [14]. In most if not all societies on the planet, eating is done in a social 
context. Individualization and, as it were, privatization of eating in plethoric societies may carry more liabilities than benefits while there may be long unsuspected benefits associated with the sharing of food in the common meal [14]. Meals are the heart and the hearth of all human groups, from the original soup, bread soaked in broth, to the 3-day wedding feasts of Bosnia or India. Eating, sharing together is the quintessential basic human activity -with sex. It has been transmogrified a few decades ago in "feeding" individuals with processed chemicals and flavors, blessed by some nutritionists whose horizon is the lab bench. In none of the 83 countries (and counting) where I have worked is the degradation of the human bonding worse than in the United States; bromides and the omnipresent empty message of "family values" are what politicians and policy makers utter, in a country where one in four children eats alone (watching commercials on junk food); where food stamps do not deliver the healthy foods poor families so badly need, but too often some amongst the worst processed ones; where our daughter Emilie was the only student in her $4^{\text {th }}$ grade class to draw a real chicken (beak, feathers and all) while the others sketched a frozen, packaged miserable bird; where most young adults will never know as fish anything but Mrs Paul's ${ }^{\circledR}$ fish fillets; where you better not drop a "vine" calibrated tomato on your toe (it will hurt!); where standard sliced sandwich bread has the texture and blandness of a Kleenex ${ }^{\circledR}$ tissue; and where people get lonesome, angry, hopeless, joyless, because they are deprived of sharing the crusty fragrant bread -the meal that we all need. My rant could stop here, but it would barely graze the surface of very complex interactions, many of them have come to light recently, for example the microbiome [15]. I cannot think of any mass-promoted diet that could possibly be beneficial to simply overweight people. These are either chastising -and rapidly abandoned-, or unaffordable, impractical. It is not because these diets are all bad; some of them are in fact pretty good, but they address a moment in time, just a given moment in the life of human, social individual, with a complex mixture of pasts, presents and visions of the future. They are not tailored, and revised, adjusted, modified, according to a myriad of interferences. How could they? And they ignore pleasure. Pleasure is not an "extra", or bonus bringing a little more soul to certain of our acts; it is a fundamental part of our animal life. It is just as difficult to define as spirit, but nonetheless humans are very conscious of it [16]. Pleasure is a potent drive, inducing forms of behavior adapted to physiological needs, for example temperature regulation and food-andfluid intake; sensory pleasure is an incentive to useful behavior, and maximization of pleasure the answer to physiological conflicts, also known as stress [17]. "The pleasures of the table are for every man, of every land, and no matter of what place in history or society; they can be a part of all other pleasures and they last the longest, to console us when we have outlived the rest." [18].

Bon Appétit!

Abbreviation

HFCS, High fructose corn syrup.

\section{Competing interests}

The author declares that he currently has no competing interests.

\section{Acknowledgements}

The author thanks Claude Fischler, PhD for his comments, corrections and suggestions, and the editors of Flavour for inviting him to write this Op-Ed; it is obviously subject to changes, inherent to the nature of the subject, and the endless flow of scientific evidence that can only be compared to the tip of an iceberg.

Received: 3 July 2012 Accepted: 29 August 2012

Published: 19 September 2012

\section{References}

1. Dorfman L, Cheyne A, Friedman LC, Wadud A, Gottlieb M: Soda and tobacco industry corporate social responsibility campaigns: how do they compare? PLoS Med 2012, 9(6):e1001241. doi:10.1371/journal.pmed.1001241.

2. http://en.wikipedia.org/wiki/Nestl\%C3\%A9\#cite_note-9.

3. Sweetness http://en.wikipedia.org/wiki/Sweetness.

4. Mitchell A, Waltman PA: Oral sucrose and pain relief for preterm infants. Pain Manag Nurs 2003, 4:62-69.

5. Slater R, Cornelissen L, Fabrizzi L, Patten D, Yoxen J, Worley A, Boyd S, Meek J, Fitzgerald M: Oral sucrose as an analgesic drug for procedural pain in newborn infants: a randomised controlled trial. Lancet 2010, 376:1225-1232.

6. http://en.wikipedia.org/wiki/High-fructose_corn_syrup_and_health

7. Stanhope KL, Havel PJ: Fructose consumption: considerations for future research on its effects on adipose distribution, lipid metabolism and insulin sensitivity in humans. J Nutr 2009, 139:1236S-1241S.

8. Lustig RH: Fructose: metabolic, hedonic, and societal parallels with ethanol. J Am Diet Assoc 2010, 110:1307-1321.

9. Hayes JE: Transdisciplinary perspectives on sweetness. Chemosensory Percept 2008, 1:48-57.

10. Melchior JC, Rigaud D, Colas-Linhart N, Petiet A, Girard A, Apfelbaum M: Immunoreactive beta-endorphin increases after an aspartame chocolate drink in healthy human subjects. Physiol Behav 1991, 50:941-944.

11. Drewnowski A, Almiron-Roig E: Human Perceptions and Preferences for Fat-Rich Foods. In Fat Detection: Taste, Texture, and Post Ingestive Effects. Edited by Montmayeur JP, le Coutre J. Boca Raton FL: CRC Press; 2010. Chapter 11. Frontiers in Neuroscience.

12. Johnson PM, Kenny PJ: Dopamine D2 receptors in addiction-like reward dysfunction and compulsive eating in obese rats. Nat Neurosci 2010, 13:635-641.

13. Lowe MR, Butryn ML: Hedonic hunger: a new dimension of appetite? Physiol Behav 2007, 91:432-439.

14. Fischler C: The nutritional cacophony may be detrimental to your health. Progr Nutr 2011, 13:217-221.

15. Krajmalnik-Brown R, Ithan ZE, Kang DW, DiBaise JK: Effects of gut microbes on nutrient absorption and energy regulation. Nutr Clin Pract 2012, 27:201. doi:10.1177/088453311436116.

16. Vincent JD: Biology of pleasure. Presse Med 1994, 23:18711873.

17. Cabanac M: Preferring the pleasure. Am J Clin Nutr 1985, 42:1151-1155.

18. Brillat-Savarin J-A: Physiologie du Goût ou Méditations de Gastronomie Transcendante. Ouvrage théorique, historique et à l'ordre du jour, dédié aux Gastronomes parisiens, par un Professeur, membre de plusieurs sociétés littéraires et savantes. Paris: Chez A. Sautelet et Cie. Libraires; 1826.

doi:10.1186/2044-7248-1-17

Cite this article as: Halpern: "We only eat what we like" or do we still?. Flavour 2012 1:17. 